\title{
Summer water temperature of lowland Mazovian rivers in the context of fisheries management
}

\author{
Maksym Łaszewski
}

Received - 25 November 2015/Accepted - 21 January 2016. Published online: 31 March 2016; ○Inland Fisheries Institute in Olsztyn, Poland Citation: Łaszewski M. 2016 - Summer water temperature of lowland Mazovian rivers in the context of fisheries management - Arch. Pol. Fish. 24: 3-13

\begin{abstract}
Water temperatures in three upstream and three downstream profiles of the Jeziorka, Swider, and Utrata rivers were recorded in the summer period of hydrological year 2015 using digital data loggers. The measurement data was used to estimate statistical and ecological thermal parameters. The results demonstrated that water temperature in the studied lowland rivers was quite similar, except in the downstream reaches of the Utrata River, which is subjected to strong anthropogenic modification. The best thermal conditions for the survival and growth of the cold-water fish assemblage were observed upstream in the Jeziorka River in Głuchów, while the worst were downstream in the Utrata River in Nowy Łuszczewek. However, the results suggest that in quasi-natural rivers, such as the Jeziorka and Świder, cold-water fish can exist and be stocked in both the upstream and downstream segments. For the warm-water fish assemblage, the best thermal conditions were noted downstream in the Utrata River, while the worst were upstream in the Swider River; nevertheless, differences between the rivers were relatively small. The results of the analysis have practical implications for managing these waters with a view to optimizing angling and natural resources.
\end{abstract}

Keywords: fisheries management, Mazovian rivers, thermal requirements, water temperature

\footnotetext{
Maksym Łaszewski[ [ڤ]

Department of Hydrology, Institute of Physical Geography

Faculty of Geography and Regional Studies,

University of Warsaw, Poland

e-mail: m.laszewski@uw.edu.pl
}

\section{Introduction}

Water temperature has a critical impact on stream ecology (Coutant 1976). It determines oxygen solubility, the rate of biochemical reactions, and the toxicity of substances (Cairns et al. 1978, Poole and Berman 2001, Caissie 2006). Moreover, water temperature is crucial to fisheries management, because all life stages of fish are regulated by stream thermal regime (Beschta et al. 1987, Crisp 1989, Armour 1994). This is confirmed by numerous studies and concerns issues such as fish survival (Selong et al. 2001, Boyd et al. 2010), growth rates (Marine and Cech 2004, Handeland et al. 2008), gamete maturation (Lahnsteiner and Kletzl 2012), egg development, and time of hatching (Kucharczyk et al. 1997, Berg and Moen 1999). In addition, much attention is being paid to climate change and its potential impact on fish populations (Eaton and Sheller 1996, Webb and Walsh 2004, Hari et al. 2006). Accordingly, the optimization and appropriate management of fisheries requires determining river water temperature both temporally and spatially, especially in streams inhabited by economically important fish species.

Thermal criteria for fish in Poland are defined in the Regulation of the Minister of the Environment of October 4, 2002, which sets forth fish requirements in inland habitats under natural conditions. However, these criteria only take into account the

\footnotetext{
C Copyright by Stanisław Sakowicz Inland Fisheries Institute in Olsztyn.

(c) 2016 Author(s). This is an open access article licensed under the Creative Commons Attribution-NonCommercial-NoDerivs License (http://creativecommons.org/licenses/by-nc-nd/3.0/).
} 
maximum permissible water temperature in rivers below sources of thermal pollution, and simple threshold values of lethal water temperatures (e.g., $21.5^{\circ} \mathrm{C}$ for salmonids and $28^{\circ} \mathrm{C}$ for cyprinids) seems not to be justified ecologically. Modern fisheries management and environmental protection requires the use of complex parameters that describe thermal regimes in terms of the survival, growth, and reproduction of freshwater fish (Sullivan et al. 2000). Comprehensive compilations of such parameters can be found in numerous publications and reports from Germany (Küttel et al. 2002), Canada (Hasnain et al. 2010), the UK (Alabaster and Lloyd 1982, Solomon and Lightfoot 2008), and the U.S. (Brungs and Jones 1977, McCullough 1999).

This study aims to compare water temperatures in three lowland Mazovian rivers during the summer period of hydrological year 2015. The specific objectives are: (1) to characterize diversity of water temperature on a relatively small spatial scale; (2) to quantify its suitability in terms of cold-water and warm-water fish assemblage thermal requirements. The results of the analysis have practical implications for the management of these waters with a view to optimizing angling and natural resources.

\section{Study area}

The study was carried out in the Jeziorka, Swider, and Utrata rivers that flow through the Mazovian Voivodeship in central Poland (Fig. 1). The rivers cross glacier depositional plains comprised of sedimentary rocks - mainly clay and sand. The river catchments are characterized by a temperate climate with average annual air temperature of $8-9^{\circ} \mathrm{C}$ and average annual precipitation of approximately $550-600 \mathrm{~mm}$. Land use is dominated by agriculture with a small contribution of forests, which do not exceed $25 \%$ of the total catchment area.

The Jeziorka River is a left tributary of the Vistula River with a length of $66.3 \mathrm{~km}$ and a catchment area of $975.3 \mathrm{~km}^{2}$. The average annual flow rate at the hydrometric profile in Piaseczno in the 1990-2014 period was $2.8 \mathrm{~m}^{3} \mathrm{~s}^{-1}$. Some parts of the Jeziorka River are subjected to strong anthropogenic pressure, and there are 17 weirs mainly located in the upper and middle parts of the river.

The Świder River is right tributary of the Vistula River with a total length of $99.9 \mathrm{~km}$ and a catchment area of $1160.7 \mathrm{~km}^{2}$. The average annual flow rate at the Otwock-Wólka Mlądzka hydrometric gauging station for the 1990-2014 period was $4.2 \mathrm{~m}^{3} \mathrm{~s}^{-1}$. The Swider River is characterized by varied morphology. The middle reaches of the river was regulated, while the downstream part is protected as a nature reserve and is of a quasi-natural character, with numerous riffles, boulders, and a dense riparian canopy.

The Utrata River, a right tributary of the Bzura River, has a total length of $76.5 \mathrm{~km}$ and a catchment area of $792 \mathrm{~km}^{2}$. The average annual flow rate at the Krubice hydrometric gauging station for the 1990-2014 period was $3.1 \mathrm{~m}^{3} \mathrm{~s}^{-1}$. The Utrata River is strongly modified and long segments of the river, especially in the middle and downstream sections, have been subjected to total regulation, including the complete removal of riparian vegetation. The upstream part maintains a quasi-natural character.

The ichthyofauna of the investigated rivers is represented by diverse species, which is the result of the varied morphological and hydrological parameters of the rivers. Few publications refer to this issue; evaluations of the ichthyofauna based on electrofishing were carried out only by Rembiszewski (1964), Borzęcka et al. (2002), and Borzęcka et al. (2012). The investigated rivers are mainly inhabited by roach, Rutilius rutilius (L.), chub, Squalius cephalus (L.), dace, Leuciscus leuciscus (L.), ide, Leuciscus idus (L.), perch, Perca fluviatilis L., pike, Esox lucius L, burbot, Lota lota (L.), and gudgeon, Gobio gobio (L.). There is a population of brown trout, Salmo trutta L. in the upstream part of the Jeziorka River and in the downstream part of the Swider River, where grayling, Thymallus thymallus (L.) is also present (Oglęcki and Pawłat 2005, Cios and Stępniak 2011). The Jeziorka and Utrata rivers are managed by the Polish Angling Association and stocked with several fish species, including pike, chub, and brown trout (Polish Angling 
Table 1

List of economically important fish species stocked by the Polish Angling Association in 2009-2014

\begin{tabular}{ll} 
River & Fish species \\
\hline \hline Jeziorka & $\begin{array}{l}\text { Pike, common nase, chub, ide, brown trout } \\
\text { (only upper part) }\end{array}$ \\
& $\begin{array}{l}\text { Pike, common nase, common barbel, chub, } \\
\text { Swider }\end{array}$ \\
Utrata & Pike, ide \\
\hline \hline
\end{tabular}

Association, unpublished data) (Table 1). Most of the Świder River is managed by the Regional Directorate for Environment Protection in Warsaw, although the Polish Angling Association stocks the sections of the river that are not part of the nature reserve.

\section{Materials and methods}

Water temperature data was obtained from field measurements using HOBO U22-001 digital data loggers (Onset Comp. Corp., USA) deployed in upstream and downstream segments of each river (Fig. 1). The data loggers were installed inside perforated tubes made of PVC, which were bolted to a small, concrete blocks. This solution ensured that the device was in constant

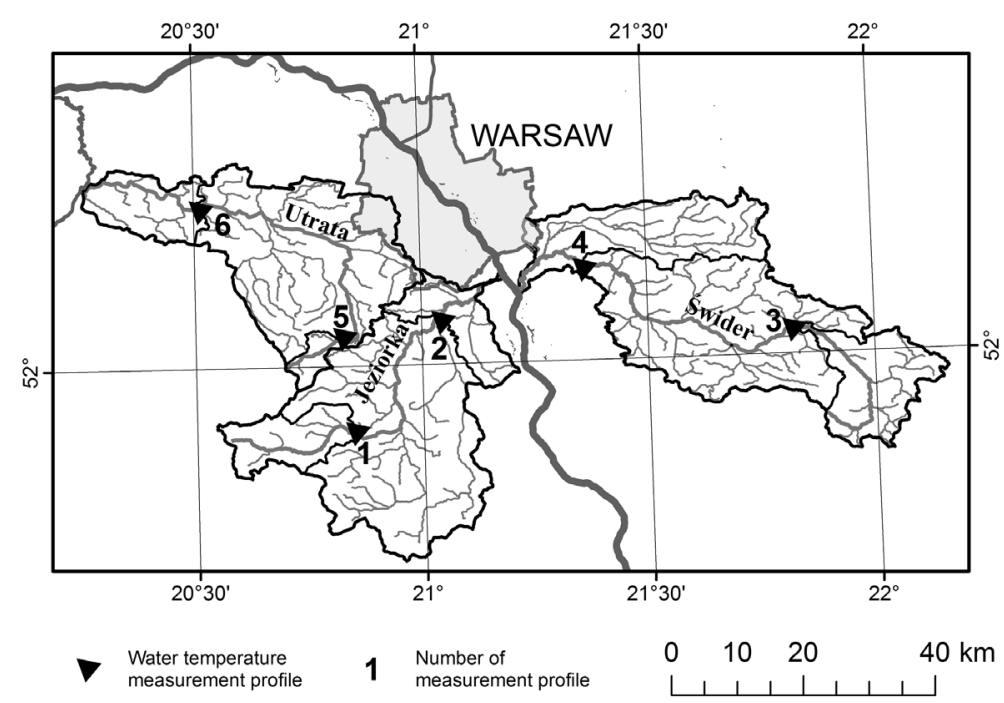

Figure 1. Catchment area of the studied rivers and location of water temperature measurement profiles. contact with flowing water and was protected from direct solar radiation. Loggers with their housings were placed in the central part of channel riffles at a depth of about 40-60 cm, where good mixing of water molecules meant that the cross-sectional temperature gradient was not observed. The time interval between successive measurements was 30 minutes, while the precision of the devices, according to the manufacturer, was $0.2^{\circ} \mathrm{C}$. Temperature measurements covered the summer period of hydrological year 2015 exactly from 1 May to 31 October, which is a critical period for fish survival and growth. During the period studied, the data loggers were also inspected with an electronic thermometer with an accuracy of $0.1^{\circ} \mathrm{C}$; the temperature differences between handheld and automatic measurements reached maximum values of $0.1^{\circ} \mathrm{C}$, which permitted comparing water temperatures.

A brief description of the measurement profiles is presented in Table 2. Distance from sources and catchment area were calculated using digital hydrographic maps and ArcGIS 10.0 software. Riparian shade was simply evaluated using orthophotomaps after Johnson et al. (2014), and it was estimated as a percentage of shaded river reach $5 \mathrm{~km}$ upstream from each profile. River width was measured directly in the study area.

Basic statistical parameters were estimated using the measurement data. For each month of the investigated period, the average monthly temperature, maximum monthly temperature, and monthly water temperature range were determined. Ecological parameters, which describe water temperature in terms of the requirements of the cold-water and warm-water fish assemblages, were also calculated. It was assumed that the parameters for cold-water assemblage are representative of brown trout and grayling, while parameters for the warm-water assemblage are representative of cyprinids (roach, chub) and pike (Table 3). The duration of the optimum 
Table 2

Detailed description of measurement profiles

\begin{tabular}{llllll}
\hline $\begin{array}{l}\text { Number of } \\
\text { profile }\end{array}$ & Measurement profile & $\begin{array}{l}\text { Distance from } \\
\text { springs }(\mathrm{km})\end{array}$ & $\begin{array}{l}\text { Catchment area } \\
\left(\mathrm{km}^{2}\right)\end{array}$ & $\begin{array}{l}\text { Average river width } \\
(\mathrm{m})\end{array}$ & $\begin{array}{l}\text { Riparian shade } \\
5 \mathrm{~km} \text { upstream }(\%)\end{array}$ \\
\hline \hline 1 & Jeziorka - Głuchów & 23.5 & 137.8 & 4.0 & 77.0 \\
2 & Jeziorka - Piaseczno & 57.3 & 853.8 & 10.0 & 72.0 \\
3 & Swider - Latowicz & 31.4 & 219.5 & 4.0 & 5.0 \\
4 & Swider - Adamówka & 79.2 & 853.3 & 12.0 & 73.0 \\
5 & Utrata - Jastrzębiec & 10.3 & 35.6 & 2.0 & 74.0 \\
6 & Utrata - Nowy Euszczewek & 55.0 & 661.0 & 9.0 & 0.0 \\
\hline \hline
\end{tabular}

Table 3

Thermal requirements of selected freshwater fish species present in the investigated rivers. Based on Elliott (1981) and Küttel et al. (2002)

\begin{tabular}{lll}
\hline \hline & $\begin{array}{l}\text { Optimum } \\
\text { temperature }\left({ }^{\circ} \mathrm{C}\right)\end{array}$ & $\begin{array}{l}\text { Upper incipient } \\
\text { lethal temperature } \\
\left({ }^{\circ} \mathrm{C}\right)\end{array}$ \\
\hline \hline Roach & $8-25$ & 28 \\
Chub & $8-25$ & 27 \\
Pike & $9-25$ & $29-30$ \\
Brown trout & $4-19$ & 25 \\
Grayling & $4-18$ & $24-26$ \\
\hline \hline
\end{tabular}

temperature for cold-water $\left(4-19^{\circ} \mathrm{C}\right)$ and warm-water $\left(8-25^{\circ} \mathrm{C}\right)$ assemblages was estimated for each month in percentages. The optimum temperature was assumed to be the range within which fish exhibit positive growth and the best condition, activity, and feeding. During the three hottest months, from July to September, the duration of temperatures above the upper incipient lethal temperature for the cold-water assemblage (assumed as $25^{\circ} \mathrm{C}$ ), which is considered to be the limit above which $50 \%$ of the population of mature fish can survive for a short period of time (usually 7 days) was also calculated (Elliott 1981, Hokanson 1990). It must be emphasized that exceeding this threshold does not mean immediate fish death. Values of ecological parameters were adopted from Elliott (1981) and
Küttel et al. (2002). All statistics were calculated with the analytical software Statistica.

\section{Results}

The water temperature of the surveyed rivers in the summer period of hydrological year 2015 showed clear diversity (Table 4) in terms of both average and maximum values. The lowest half-year average water temperature $\left(15.4^{\circ} \mathrm{C}\right)$ was noted in the upstream reaches of the Utrata River in Jastrzębiec, while the highest was observed downstream in the Utrata River in Nowy Łuszczewek $\left(17.9^{\circ} \mathrm{C}\right)$. The monthly average water temperature for all rivers was the lowest in October and ranged from $7.9^{\circ} \mathrm{C}$ in the upstream Jeziorka and Utrata rivers to $10.3^{\circ} \mathrm{C}$ in the downstream Utrata River. The highest average monthly temperature was observed in August and ranged from $19.0^{\circ} \mathrm{C}$ in the upper Utrata River to $22.3^{\circ} \mathrm{C}$ in the downstream Utrata River (Fig. 2). On average, the upstream parts of the river were colder than the downstream parts, with maximum differences of $2.5^{\circ} \mathrm{C}$ in the case of the Utrata River.

The maximum monthly temperature and monthly range varied within each river and among them (Table 4). The absolute maximum water temperature in the summer half-year was observed in August and ranged from $24.5^{\circ} \mathrm{C}$ in the upstream Jeziorka River in Głuchów to $27.8^{\circ} \mathrm{C}$ in the downstream Utrata River. The absolute 


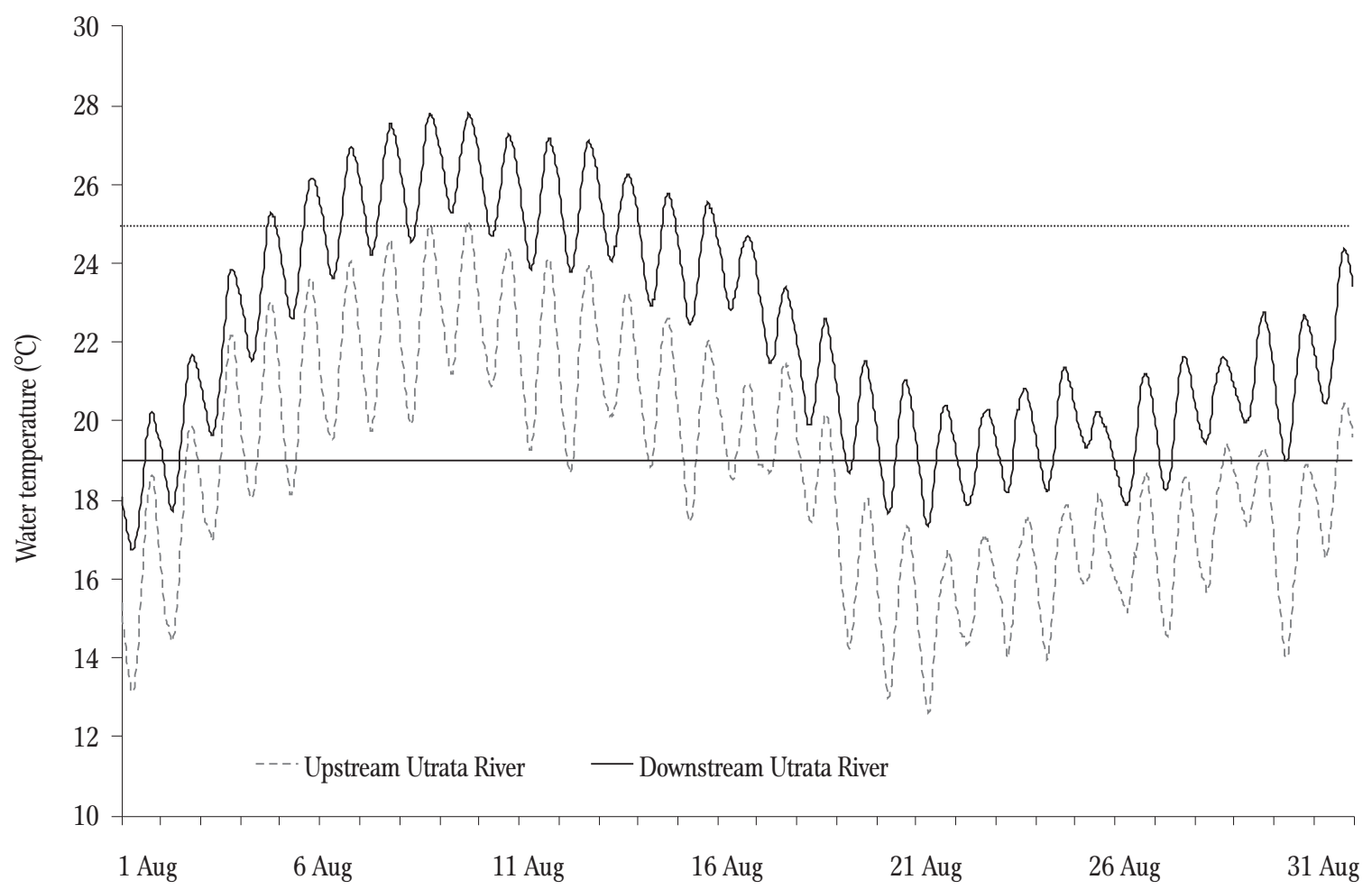

Figure 2. Water temperature of the Utrata River in August 2015 in upstream (Jastrzębiec) and downstream reaches (Nowy Łuszczewek). Solid horizontal line indicates upper threshold of cold-water assemblage optimum temperature, while the dashed line indicates the upper incipient lethal temperature threshold for the cold-water assemblage.

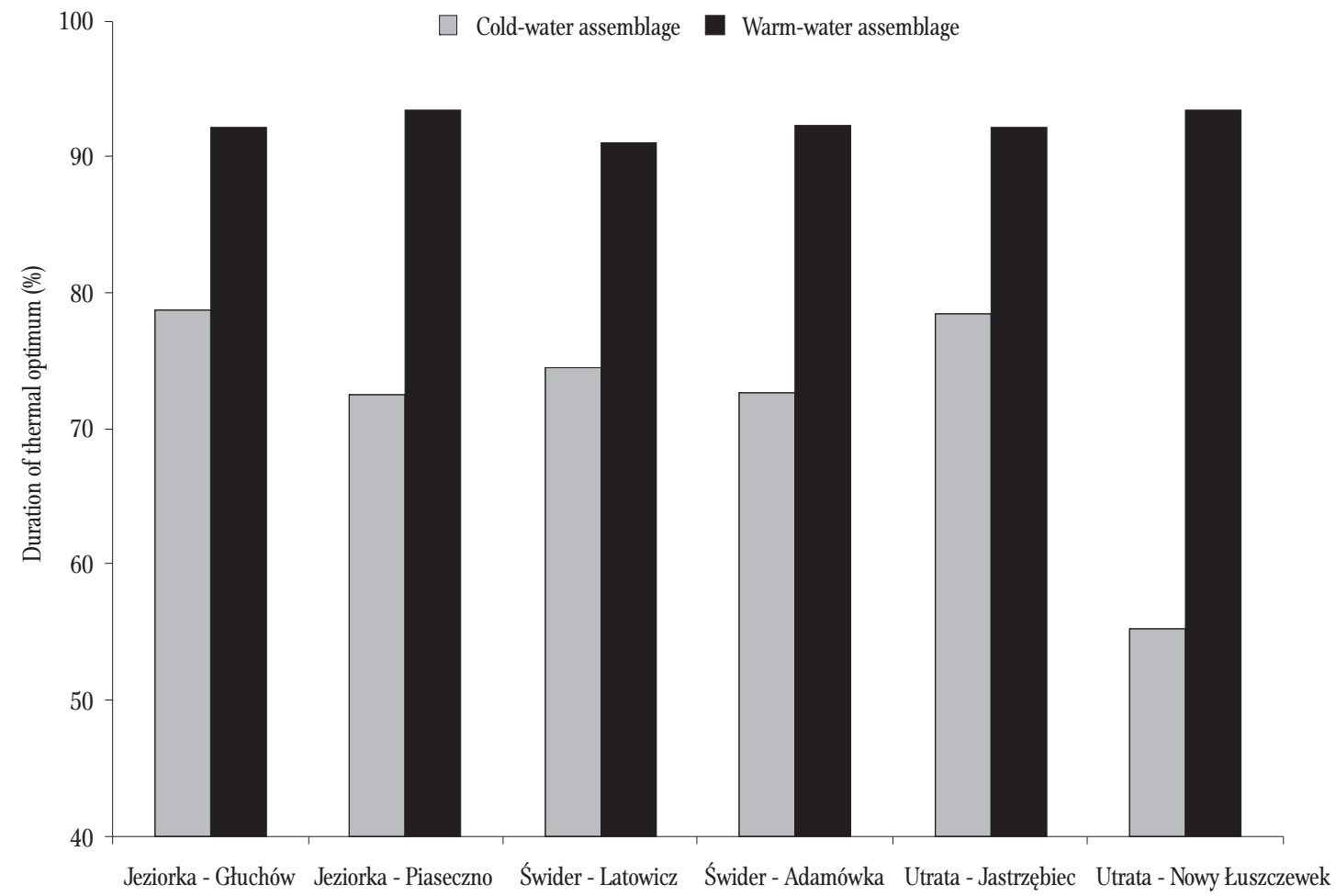

Figure 3. Optimum temperature duration for cold-water and warm-water fish assemblages during the summer period of hydrological year 2015 . 
Table 4

Statistical parameters of the thermal regime of the investigated rivers in the summer period of hydrological year 2015

\begin{tabular}{|c|c|c|c|c|c|c|c|c|c|}
\hline Parameter & River & Profile & $\mathrm{V}$ & VI & VII & VIII & IX & $\mathrm{X}$ & Half-year \\
\hline \multirow{6}{*}{$\begin{array}{l}\text { Monthly average } \\
\text { temperature }\left({ }^{\circ} \mathrm{C}\right)\end{array}$} & \multirow{2}{*}{ Jeziorka } & Głuchów & 14.2 & 17.6 & 19.0 & 19.3 & 14.8 & 7.9 & 15.5 \\
\hline & & Piaseczno & 14.5 & 18.2 & 19.9 & 20.3 & 15.7 & 8.6 & 16.2 \\
\hline & \multirow[t]{2}{*}{ Swider } & Latowicz & 13.7 & 17.6 & 19.6 & 20.1 & 15.1 & 8.0 & 15.7 \\
\hline & & Adamówka & 14.0 & 17.9 & 20.0 & 20.4 & 15.6 & 8.1 & 16.0 \\
\hline & \multirow[t]{2}{*}{ Utrata } & Jastrzębiec & 14.5 & 17.5 & 19.0 & 19.0 & 14.7 & 7.9 & 15.4 \\
\hline & & Łuszczewek & 15.9 & 20.1 & 21.6 & 22.3 & 17.2 & 10.3 & 17.9 \\
\hline \multirow{6}{*}{$\begin{array}{l}\text { Maximum } \\
\text { monthly } \\
\text { temperature }\left({ }^{\circ} \mathrm{C}\right)\end{array}$} & \multirow[t]{2}{*}{ Jeziorka } & Głuchów & 18.5 & 22.8 & 23.7 & 24.5 & 21.3 & 12.5 & 24.5 \\
\hline & & Piaseczno & 17.7 & 21.9 & 24.1 & 25.5 & 22.8 & 12.8 & 25.5 \\
\hline & \multirow[t]{2}{*}{ Świder } & Latowicz & 19.0 & 24.5 & 25.4 & 25.9 & 21.5 & 13.9 & 25.9 \\
\hline & & Adamówka & 16.6 & 22.2 & 24.7 & 26.1 & 22.1 & 12.2 & 26.1 \\
\hline & \multirow[t]{2}{*}{ Utrata } & Jastrzębiec & 19.5 & 24.1 & 24.5 & 25.1 & 21.3 & 13.6 & 25.1 \\
\hline & & Łuszczewek & 19.4 & 23.5 & 25.9 & 27.8 & 25.1 & 15.6 & 27.8 \\
\hline \multirow{6}{*}{$\begin{array}{l}\text { Monthly range of } \\
\text { temperature }\left({ }^{\circ} \mathrm{C}\right)\end{array}$} & \multirow{2}{*}{ Jeziorka } & Głuchów & 8.8 & 9.2 & 9.0 & 10.3 & 10.2 & 8.4 & 20.4 \\
\hline & & Piaseczno & 6.5 & 7.3 & 8.8 & 10.0 & 10.7 & 7.5 & 20.2 \\
\hline & \multirow[t]{2}{*}{ Świder } & Latowicz & 8.9 & 11.3 & 10.7 & 12.0 & 10.8 & 10.3 & 22.3 \\
\hline & & Adamówka & 5.8 & 7.5 & 9.0 & 10.6 & 10.3 & 7.4 & 21.4 \\
\hline & \multirow[t]{2}{*}{ Utrata } & Jastrzębiec & 10.6 & 11.2 & 10.6 & 12.4 & 10.9 & 11.0 & 22.5 \\
\hline & & Łuszczewek & 7.8 & 6.6 & 9.0 & 11.1 & 11.9 & 9.2 & 21.4 \\
\hline
\end{tabular}

maximum water temperature in the studied period was higher in all rivers in the downstream parts, by $2.7^{\circ} \mathrm{C}$ in the case of the Utrata River, but on a monthly time scale, higher maximum water temperatures were observed upstream with a difference of $2.3^{\circ} \mathrm{C}$ in the case of the Swider River in May. The absolute half-year water temperature range, similar to maximum temperature, was higher in the upstream profiles and ranged from 0.2 to $1.1^{\circ} \mathrm{C}$. The highest temperature range was observed in the upstream reaches of the Świder and Utrata rivers, while the lowest was characteristic of the downstream reaches of the Jeziorka and Swider rivers.

Ecological parameters that describe the duration of optimum water temperature for cold-water and warm-water fish assemblages in the summer period of hydrological year 2015 also varied (Table 5). Generally, the duration of the optimum temperature for warm-water species was longer than that for cold-water species in all of the investigated rivers (Fig. 3). The best thermal conditions for cold-water species were noted in the upstream reaches of the Jeziorka River in Głuchów, while for warm-water species they were noted in the downstream reach of the Utrata River in Nowy Łuszczewek. Moreover, the duration of the thermal optimum for cold-water fishes was longer in the upstream profiles by as much as $23.2 \%$ of the month, although in the case of the Jeziorka and Swider rivers there was only a slight difference of 6.2 and $1.9 \%$ of the month, respectively. In contrast, the duration of optimum water temperatures for warm-water fishes was insignificantly longer in the downstream parts at a difference of $1.2-1.3 \%$ of the month. 
Table 5

Ecological parameters of the thermal regime of the investigated rivers in the summer period of hydrological year 2015

\begin{tabular}{|c|c|c|c|c|c|c|c|c|c|}
\hline Parameter & River & Profile & $\mathrm{V}$ & VI & VII & VIII & IX & $\mathrm{X}$ & Half-year \\
\hline \multirow{4}{*}{$\begin{array}{l}\text { Optimum } \\
\text { temperature for } \\
\text { cold-water } \\
\text { assemblage } \\
4-19^{\circ} \mathrm{C}(\%)\end{array}$} & \multirow[t]{2}{*}{ Jeziorka } & Głuchów & 100 & 77.4 & 51.6 & 48.7 & 94.4 & 100 & 78.7 \\
\hline & & Piaseczno & 100 & 67.1 & 37.5 & 38.3 & 92.2 & 100 & 72.5 \\
\hline & \multirow[t]{2}{*}{ Świder } & Latowicz & 100 & 71.8 & 42.0 & 39.9 & 95.0 & 98.3 & 74.5 \\
\hline & & Adamówka & 100 & 74.4 & 34.0 & 34.9 & 92.2 & 100 & 72.6 \\
\hline \multirow{8}{*}{$\begin{array}{l}\text { Optimum } \\
\text { temperature for } \\
\text { warm-water } \\
\text { assemblage } \\
8-25^{\circ} \mathrm{C}(\%)\end{array}$} & \multirow[t]{2}{*}{ Utrata } & Jastrzębiec & 99.1 & 75.2 & 52.3 & 53.8 & 92.7 & 97.3 & 78.4 \\
\hline & & Łuszczewek & 98.7 & 30.6 & 12.6 & 12.7 & 76.3 & 100 & 55.2 \\
\hline & \multirow[t]{2}{*}{ Jeziorka } & Głuchów & 100 & 100 & 100 & 100 & 100 & 53.0 & 92.2 \\
\hline & & Piaseczno & 100 & 100 & 100 & 98.5 & 100 & 61.8 & 93.4 \\
\hline & \multirow[t]{2}{*}{ Świder } & Latowicz & 100 & 100 & 99.5 & 95.2 & 100 & 51.9 & 91.1 \\
\hline & & Adamówka & 100 & 100 & 100 & 95.8 & 100 & 58.1 & 92.3 \\
\hline & \multirow[t]{2}{*}{ Utrata } & Jastrzębiec & 100 & 100 & 100 & 99.8 & 100 & 53.5 & 92.2 \\
\hline & & Łuszczewek & 100 & 100 & 96.6 & 77.3 & 99.7 & 87.3 & 93.5 \\
\hline
\end{tabular}

The incipient lethal temperature for the cold-water assemblage was exceeded only in certain months (Table 6). The longest duration and the highest exceedance of water temperature above the incipient lethal threshold were observed in August in all of the investigated rivers, excluding the upstream Jeziorka River in Głuchów, where a temperature of $25^{\circ} \mathrm{C}$ was not reached. The lethal incipient threshold was also exceeded in July (Utrata and Świder rivers) and September (Utrata River). The maximum duration of temperatures above the incipient lethal threshold lasted for 169 hours in the downstream reach of the Utrata River, with maximum exceedance of $2.8^{\circ} \mathrm{C}$. Insignificant, short exceedances of the lethal incipient threshold were observed in the downstream reach of the Jeziorka River and in the upper reach of the Utrata River.

\section{Discussion}

The data presented can be used to characterize river water temperature and quantify its suitability for two fish assemblages. Similar studies, in which ecological water temperature parameters are calculated, although on a smaller spatial scale, have been published by Łaszewski and Jeleński (2013) in the case of the foothill Raba River and the lowland Swider River, as well as by Radtke and Dobosz (2015) in case of the Radunia River. Ecological parameters related to brown trout thermal requirements were also used by Broadmeadow et al. (2011) for UK rivers. The parameters used in the current investigation do not take into account optimal conditions for spawning and egg development. The reason is that most fish species occurring in lowland Mazovian rivers spawn in spring, while the spawning grounds they use are usually located in tributaries where thermal conditions differ (Beschta et al. 1987).

This study demonstrates that the water temperature of lowland rivers was quite similar because of the relatively small, homogeneous geographical area mainly in terms of hydrological regime, climate, and land use. Slight differences were evident especially during hot periods, when shading, which is diversified in the case of the investigated rivers, significantly affected the thermal regime (Malcolm et al. 2008, Simmons et al. 2015). The upstream parts of the 
Table 6

Duration and maximum exceedance of the lethal temperature threshold for the cold-water fish assemblage in the summer months of hydrological year 2015

\begin{tabular}{|c|c|c|c|c|c|}
\hline Parameter & River & Profile & VII & VIII & IX \\
\hline \multirow{6}{*}{$\begin{array}{l}\text { Incipient lethal temperature duration for } \\
\text { cold-water assemblage (h) }\end{array}$} & \multirow[t]{2}{*}{ Jeziorka } & Głuchów & 0.0 & 0.0 & 0.0 \\
\hline & & Piaseczno & 0.0 & 11 & 0.0 \\
\hline & \multirow[t]{2}{*}{ Swider } & Latowicz & 4.0 & 35 & 0.0 \\
\hline & & Adamówka & 0.0 & 31 & 0.0 \\
\hline & \multirow[t]{2}{*}{ Utrata } & Jastrzębiec & 0.0 & 1.5 & 0.0 \\
\hline & & Nowy Łuszczewek & 25 & 169 & 2.5 \\
\hline \multirow{6}{*}{$\begin{array}{l}\text { Maximum exceedance of incipient lethal } \\
\text { temperature }\left({ }^{\circ} \mathrm{C}\right)\end{array}$} & \multirow[t]{2}{*}{ Jeziorka } & Głuchów & 0.0 & 0.0 & 0.0 \\
\hline & & Piaseczno & 0.0 & 0.5 & 0.0 \\
\hline & \multirow[t]{2}{*}{ Świder } & Latowicz & 0.4 & 0.9 & 0.0 \\
\hline & & Adamówka & 0.0 & 1.1 & 0.0 \\
\hline & \multirow[t]{2}{*}{ Utrata } & Jastrzębiec & 0.0 & 0.1 & 0.0 \\
\hline & & Łuszczewek & 0.9 & 2.8 & 0.1 \\
\hline
\end{tabular}

rivers, which are closer to springs, were generally colder than downstream parts, as evidenced by the lover average and maximum temperatures. However, as indicated by the higher temperature range, temperature dynamics in upstream reaches were higher than those in downstream segments, primarily because of lower heat capacity linked to lower flow rates (Poole and Berman 2001). As expected, water temperature in the downstream reaches of the Utrata River differed the most from the other investigated rivers with the highest average and maximum monthly temperatures throughout 2015 . This is associated with anthropogenic modification in the middle and downstream reaches of the Utrata River, especially channel regulation and the removal of riparian vegetation. The lack of riparian shading is considered the main cause of elevated water temperature because of the absorption of short-wave radiation, which is the primary component of river heat budgets (Broadmeadow et al. 2011, Garner et al. 2014, Johnson and Wilby 2015). It is worth noting that the relatively high temperature of the upstream reach of the Swider River in July and August (in comparison to upstream reaches of the Jeziorka and the Utrata rivers) was also probably due to the small degree of riparian shading. Therefore, the results suggest that the most important reason for differences in stream water temperature in homogenous geographical areas is anthropogenic stress and human activity.

The analysis of the ecological parameters can be of interest for fisheries management and angling optimization. The duration of optimal thermal conditions for warm-water fishes was similar in all of the investigated rivers, with very small differences in favor of the downstream reaches. As expected, the opposite results were obtained for cold-water fish assemblages; slightly better thermal conditions were observed in the colder upstream reaches. Although, in the case of the Swider and Jeziorka rivers, characterized by relatively high degree of riparian shading, only small differences were noted in cold-water assemblage optimum temperature duration between the upstream and downstream reaches. This indicates that in quasi-natural lowland rivers, cold-water fish species can exist and be stocked both in 
upstream and downstream segments. Furthermore, good thermal conditions for salmonids in these waters are confirmed by angler reports, for example, in the downstream reaches of the Świder River, where brown trout and grayling grow to sizes as large as 55 $\mathrm{cm}$ and nearly $40 \mathrm{~cm}$, respectively (Paruzel 2012, Cios and Łaszewski 2014). It should be emphasized that the management of such rivers and streams as salmonid waters is based on environmental factors, such as good productivity (Iwaszkiewicz 1965, Zalewski 1986), as well as historical occurrence. Salmonids, mainly brown trout, inhabited these streams in the past (Cios 2003). The results of this study runs counter to the prevailing belief among some fisheries managers in Central Poland, that in terms of abiotic factors, salmonids can only exist in the upper reaches of rivers, especially in mountain and submontane segments. Some researchers have also found that the water temperatures of even upstream reaches of lowland streams are unsuitable for salmonids (Policht-Latawiec and Kanownik 2012). These arguments, however, are not supported by precise water temperature data.

The results of this study are representative in the context of fish survival, because during the summer of 2015 extremely high air temperatures occurred. Consequently, water temperatures repeatedly exceeded the upper incipient lethal threshold for cold-water species $\left(25^{\circ} \mathrm{C}\right)$. In the case of the Jeziorka and Swider rivers, these thermal events were relatively short and insignificant. However, water temperature of the downstream Utrata River exceeded $25^{\circ} \mathrm{C}$ for nearly 200 hours, which, combined with low oxygen concentrations, could be stressful, cause deterioration of the overall condition of fish, and affect their migration. Therefore, the connectivity of lowland rivers with tributaries is crucial in fisheries management and for the survival of fish during low flow summer periods. Handheld measurements made by the author indicated that in the summer the water temperature of small tributaries was as much as $2-3^{\circ} \mathrm{C}$ cooler than that in the main channels of the investigated rivers.
Water temperature studies can improve the understanding of stream habitats, and, consequently, they can be applicable in fisheries management. The current study was based on precise measurement data, which permitted presenting the temperatures of small but valuable natural lowland rivers that have not yet been properly investigated from an environmental point of view. The author hopes that access to accurate, reliable water temperature data from digital data loggers will increase interest in water temperature as it relates to fish ecology, with a view to optimizing fisheries management. Such studies should be particularly valuable in the context of climate and anthropogenic changes in the environment.

Acknowledgments. The author is very grateful to Dr. Stanisław Cios for his guidance in preparing the manuscript. The author also would like to express his gratitude to the Mazovian District of the Polish Angling Association for providing data about fish stocking.

\section{References}

Alabaster J.S., Lloyd R. 1982 - Water quality criteria for freshwater fish. Second edition - Butterworth Scientific, London, England: 127-142.

Armour C.L. 1994 - Evaluating temperature regimes for protection of brown trout - U.S. Department of the Interior, National Biological Survey, Resource Publication 201,Washington DC.

Berg O.K., Moen V. 1999 - Inter- and intrapopulation variation in temperature sum requirements at hatching in Norwegian Atlantic salmon - J. Fish Biol. 54: 636-647.

Beschta R.L., Bilby R.E., Brown G.W., Holtby L.B., Hofstra T.D. 1987 - Stream temperatures and aquatic habitat: fisheries and forestry interactions - In: Streamside management: forestry and fishery interactions (Eds) E.O. Salo, Cundy T.W., University of Washington, Seattle, Washington: 191-232.

Borzęcka I., Buras P., Gasiński Z. 2002 - Characteristics of fish communities and stocks in the Swider River system Instytut Rybactwa Śródlądowego, Zakład Rybactwa Rzecznego w Żabieńcu, Żabieniec (in Polish).

Borzęcka I., Buras P., Szlakowski J., Gasiński Z., Wiśniewolski W. 2012 - The fish fauna in selected rivers of Mazovian Lowland - Fragm. Faun. 55: 75-90.

Boyd J.W., Guy C.S., Horton T.B., Leathe S.A. 2010 - Effects of catch-and-release angling on salmonids at elevated 
water temperature - North Am. J. Fish. Manage. 30: 898-907.

Broadmeadow S.B., Jones J.G., Langford T.E.L., Shaw P.J., Nisbet T.R. 2011 - The influence of riparian shade on lowland stream water temperatures in southern England and their viability for brown trout - River Res. Appl. 27: 226-237.

Brungs W.A., Jones B.R. 1977 - Temperature criteria for freshwater fish: protocol and procedures - Environmental Research Laboratory, Duluth, Minnesota.

Cairns J. Jr., Buikema A.L. Jr., Heath A.G., Parker B.C. 1978 - Effects of temperature on aquatic organism sensitivity to selected chemicals - Virginia Water Resources Research Center, Virginia.

Caissie D. 2006 - The thermal regime of the rivers: a review Freshw. Biol. 51: 1389-1406.

Cios S. 2003 - Comments on the occurrence of trout, salmon and grayling in Polish waters in the past - Rocz. Nauk. PZW 16:17-32 (in Polish).

Cios S., Stępniak T. 2011 - How weirs on the Swider River destroy the ichthyofauna - Przeg. Ryb. 35: 26-28 (in Polish).

Cios S., Łaszewski M. 2014 - Pigmentation as a natural mark on the example of trout and grayling in the Swider River Przeg. Ryb. 135: 24-25 (in Polish).

Coutant C. 1976 - Thermal effects on fish ecology - In: Encyclopedia of environmental science and engineering, Gordon and Breach Publishers, New York: 891-896.

Crisp D.T. 1989 - Some impacts of human activities on trout, Salmo trutta, populations - Freshw. Biol. 21: 21-33.

Eaton G.J., Sheller J.M. 1996 - Effects of climate warming on fish thermal habitat in stream of the United States Limnol. Oceanogr. 41: 1109-1115.

Elliott J. M. 1981 - Some aspects of thermal stress on freshwater teleosts - In: Stress and Fish (Ed.) A.D. Pickering, Academic Press, London: 209-245.

Handeland S.O., Imsland A.K., Sigurd Stefansson S.O. 2008 - The effect of temperature and fish size on growth, feed intake, food conversion efficiency and stomach evacuation rate of Atlantic salmon post-smolts - Aquaculture 283: 36-42.

Hari R.E., Livingstone D.M., Siber R., Burkhardt-Holm P., Guttinger H. 2006 - Consequences of climatic change for water temperature and brown trout populations in Alpine rivers and streams - Glob. Change Biol. 12: 10-26.

Hasnain S.S., Minns K., Shuter B.J. 2010 - Key ecological temperature metrics for canadian freshwater fishes Ontario Ministry of Natural Resources, Applied Research and Development Branch, Sault Ste. Marie, Ontario.

Hokanson K.E.F. 1990 - A national compendium of freshwater fish and water temperature data. Volume 2. Temperature requirements for 30 fishes - Archive of laboratory data base available from Technical Information Office,
Document No. ERL-DUL-2338, Environmental Research Laboratory, Duluth, Minnesota.

Iwaszkiewicz M. 1965 - Biogenity of lowland streams as the basis for their development - Rocz. WSR w Poznaniu 24: 73-107 (in Polish).

Johnson M.F., Wilby R.L., Toone J.A. 2014 - Inferring air-water temperature relationships from river and catchment properties - Hydrol. Process. 28: 2912-2928.

Johnson M.F., Wilby R.L. 2015 - Seeing the landscape from the trees: Metrics to guide riparian shade management in river catchments - Water Resour. Res. 51: 3754-3767.

Kucharczyk D., Łuczyński M., Kujawa R., Czerkies P. 1997 Effect of temperature on embryonic and larval development of bream (Abramis brama L.) - Aquat. Sci. 59: 214-224.

Küttel S., Peter A., Wüest A. 2002 - Temperaturpräferenzen und - limiten von Fischarten Schweizerischer Fliessgewässer - Rhone Revitalisierung, Publikation Nummer 1.

Lahnsteiner F., Kletzl M. 2012 - The effect of water temperature on gamete maturation and gamete quality in the European grayling (Thymalus thymallus) based on experimental data and on data from wild populations - Fish Physiol. Biochem. 38: 455-467.

Łaszewski M., Jeleński P. 2013 - A comparison of thermal conditions of the Raba River and the Swider River - Sci. Rev. Eng. Env. Sci. 61: 239-248 (in Polish).

Malcolm I., Soulsby C., Hannah D.M., Bacon P.J., Youngson A.F., Tetzlaff D. 2008 - The infuence of riparian woodland on stream temperatures: implications for the performance of juvenile salmonids - Hydrol. Process. 22: 968-979.

Marine K.R., Cech J.J. 2004 - Effects of high water temperature on growth, smoltification, and predator avoidance in juvenile Sacramento River Chinook salmon - North Am. J. Fish. Manage. 24: 198-210.

McCullough D.A. 1999 - A review and synthesis of effects of alterations to the water temperature regime on freshwater life stages of salmonids, with special reference to Chinook salmon - U.S. Environmental Protection Agency, Seattle, Washington.

Oglęcki P., Pawłat H. 2005 - Environmental conditions of Jeziorka valley and the sets towards their protection - Sci. Rev. Eng. Env. Sci. 31: 93-101 (in Polish).

Paruzel M. 2012 - Mazovian trouts - Wiadomości Wędkarskie, 05/2012 (in Polish).

Policht-Latawiec A., Kanownik W. 2012 - Quality and utility of the Radomka river above the Domaniów water reservoir - Gaz, Woda i Technika Sanitarna, 08/2012: 348-350 (in Polish).

Poole G.C., Berman C.H. 2001 - An ecological perspective on in-stream temperature:natural heat dynamics and mechanisms of human-caused thermal degradation - Environ. Manage. 27: 787-802. 
Radtke G., Dobosz S. 2015 - Thermal characteristics of Radunia River supplying water for the Rutki trout breeding center - Komun. Ryb. 137: 1-5 (in Polish).

Rembiszewski J.M. 1964 - Fish (Pisces) of the Jeziorka River and the Czarna Struga River near Warsaw - Fragm. Faun. 11: 83-102 (In Polish).

Selong J.H., McMahon T.E., Zale A.V., Barrows F.T. 2001 Effect of temperature on growth and survival of bull trout, with application of an improved method for determining thermal tolerance in fishes - T. Am. Fish. Soc. 130: 1026-1037.

Simmons J.A., Anderson M., Dress W., Hanna C., Hornbach D.J., Janmaat A., Kuserk F., March J.G., Murray T., Niedzwiecki J., Panvini D., Pohlad B., Thomas C., Vasseur L. 2015 - A comparison of the temperature regime of short stream segments under forested and non-forested riparian zones at eleven sites across North America - River Res. Appl. 31: 964-974.

Solomon D.J., Lightfoot G.W. 2008 - The thermal biology of brown trout and Atlantic salmon - Environment Agency Science Report.

Sullivan K., Martin D.J., Cardwell R.D., Toll J.E., Duke S. 2000 - An analysis of the effects of temperature on salmonids of the Pacific Northwest with implications for selecting temperature criteria - Sustainable Ecosystems Institute, Oregon. U.S. Geological Survey Scientific Investigations Report 2004-5001.

Webb B.W., Walsh A.J. 2004 - Changing UK river temperatures and their impact on fish populations - Hydrology: Science \& Practice for the 21st Century, Volume II.

Zalewski M. 1986 - Regulation of fish communities in rivers by a continuum of abiotic and biotic factors - Acta Universitatis Lodziensis, Łódź (in Polish). 